\title{
Towards a Conceptual Framework for Understanding the Attractiveness of Rail Transit-Oriented Shopping Mall Developments (TOSMDs)
}

\author{
Ayman Abutaleb $^{1}$ (D) $\cdot$ Kevin McDougall $^{2}$ (I) Marita Basson $^{2}$ (D) Rumman Hassan $^{3} \cdot$ \\ Muhammad Nateque Mahmood ${ }^{2,4}$
}

Received: 11 March 2019/Revised: 30 September 2019/Accepted: 9 October 2019/Published online: 1 November 2019

(C) The Author(s) 2019

\begin{abstract}
Transit-oriented development (TOD) links residential, retail, commercial, and community service developments to frequent, accessible rail transit services to stimulate sustainable development in the form of decreased land use and transport integration. A mixed-use shopping mall can be developed as a TOD with moderate to high density with diverse land use patterns and well-connected street networks centred around and integrated with a rail transit station. Shopping mall developments are now considered as the retail, social, and community centres of their communities. Therefore, understanding their services' mixed impact on nearby transit stations will provide further insight into the success of the TOD approach. As a result,
\end{abstract}

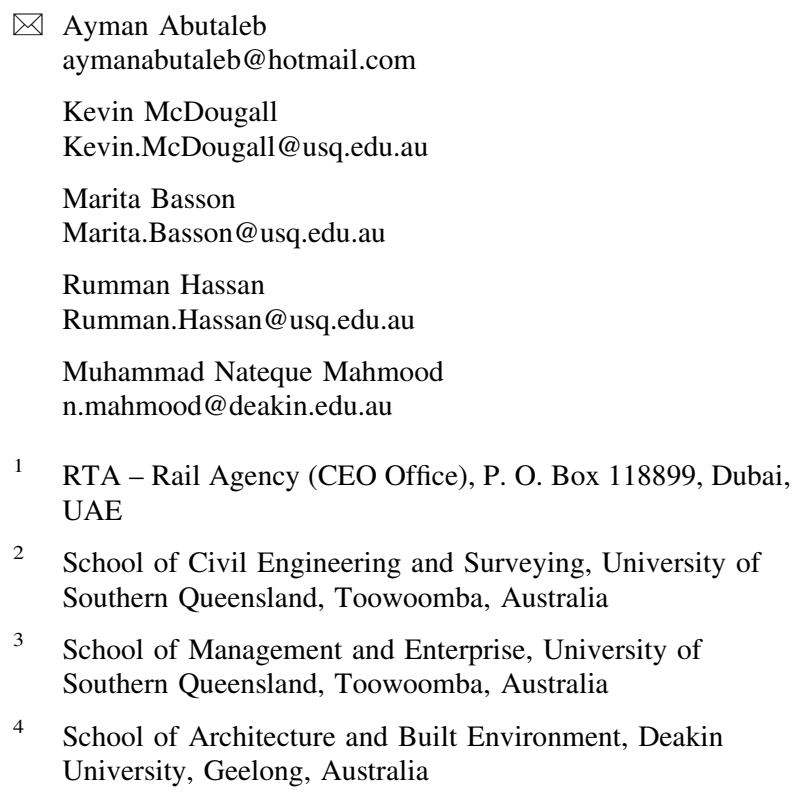

Communicated by Haixiao Pan. this study aims to review and link the recent literature on attractiveness factors of shopping malls and the design factors of TOD and report the researchers' analytic observations (themes) clarifying transit-oriented shopping mall developments' (TOSMDs) attractiveness factors. The review systematically synthesises 208 guiding articles. It uses the elements of the extended service marketing mix (product, price, place, promotion, people, physical evidence, and process) and the five factors related to TODs (density, diversity, urban design, destination accessibility, and distance) as an indicator system for the factors determining the attractiveness of TOSMD. The review outcome is utilised to establish a conceptual framework for the attractiveness of rail TOSMDs. The study revealed fragmented causes of attractiveness factors of rail TOSMDs. It contributes to further understanding of TOD as it crossreviews retail and urban design literature findings. The resultant conceptual framework will also inform and potentially enhance the existing rail transit station passenger forecasting models and increase the economic sustainability of rail transit networks.

Keywords Attractiveness factors - Shopping mall · Transit-oriented development · Rail · Design factors . Service marketing mix

\section{Introduction}

The concept of transit-oriented development (TOD) is a relatively recent development design approach that links frequent and accessible rail transit services to residential, retail, commercial, and community services [1]. The TOD concept was first proposed by an American architect Calthorpe [2] in the 1990s. It was seen as a response to rapid 
urbanisation and traffic congestion and emphasised the greater use of public transport and a reduction in private car use. The TOD approach potentially has significant implications concerning future patterns of development and land use planning in particular, and the understanding of the impact of associated developments such as shopping malls on supporting rail transport planning.

Hence, many researchers have investigated TOD as a planning strategy [3-6]. Generally, transit-oriented developments (TODs) are located within a radius of about 600-800 $\mathrm{m}$ of a rail transit station, as outlined in Fig. 1. This distance is considered an appropriate scale for pedestrians walking to and from the station [7-10]. Handy [11] postulated that TODs would serve as a "catalyst" for conserving land use and increase the density of nearby developments, including shopping malls.

With their origins in the USA over half a century ago, shopping malls have brought together multiple retail outlets and facilities within a single complex. However, the function, size, and popularity of shopping malls have changed dramatically over time. As a consequence, many researchers have attempted to shed light on the attractiveness factors of shopping malls to understand the needs of the customers, improve patronage, and increase their turnover [3, 12, 13].

The major elements of shopping malls can include retail stores, food courts, restaurants, cinemas, children's play areas, interactive entertainment, social areas, relaxation spaces, and promotional areas [14]. It was conceived that mixed-use developments such as shopping malls could increase pedestrian activity, as shown in Fig. 2, where people can easily walk to places where they can shop, eat, and play [15]. A mixed-use shopping mall can be developed as a transit-oriented development (TOD), where shoppers drive their cars less and ride nearby mass transit
[16]. It is characterised by the creation of a mix of land use and residential density development around rail transit stations to attract customers, with access mainly by foot rather than by cars [17].

A lack of planning and vision has led to poorly designed, accessed, and located developments and to marketplace congestion [18]. The level of human congestion is also likely to be higher due to the wider assortment of services and products provided by shopping malls [3]. Also, the development of shopping mall facilities can contribute to making a rail station area more attractive and potentially increase the potential customer base for the shopping mall [19]. Therefore, in order to better understand and plan for the future demands of TODs that incorporate shopping malls as a key component of the infrastructure, there is a need to consider the attractiveness or "pull" factors of these shopping malls as part of a TOD. The attractiveness factors of transit-oriented shopping mall developments (TOSMDs) are not specifically addressed in the literature. The majority of researchers distinguish between attractiveness factors of shopping malls and design factors of TODs. They are studied separately in retail and urban planning literature, respectively. Therefore, a literature review of both types of factors was essential to identify the attractiveness factors of TOSMDs and establish a conceptual framework for TOSMD attractiveness. The proposed framework will lay the foundation for understanding the extent of shopper passengers using a rail transit station near a TOSMD and potentially enhance existing forecasting models used to estimate the number of passengers using a rail transit station.

Therefore, this study is structured and organised as follows. Section 2 of the paper presents a literature review and findings in the fields of attractiveness factors of shopping malls and design factors of TODs. Section 3
Fig. 1 A basic structure of the TOD community. Adapted from Mingqiao et al. [5]

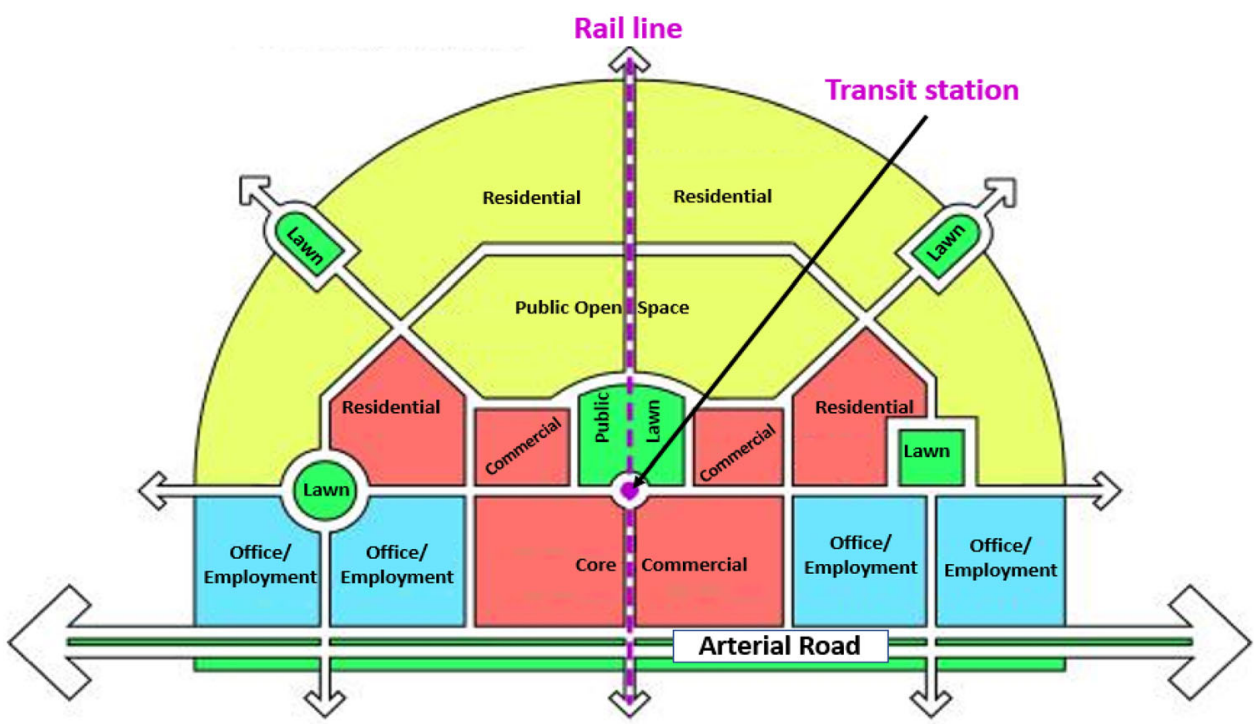


Fig. 2 Example of residential walkways to shopping malls in a TOD community. Adapted from Rajagopal [3]

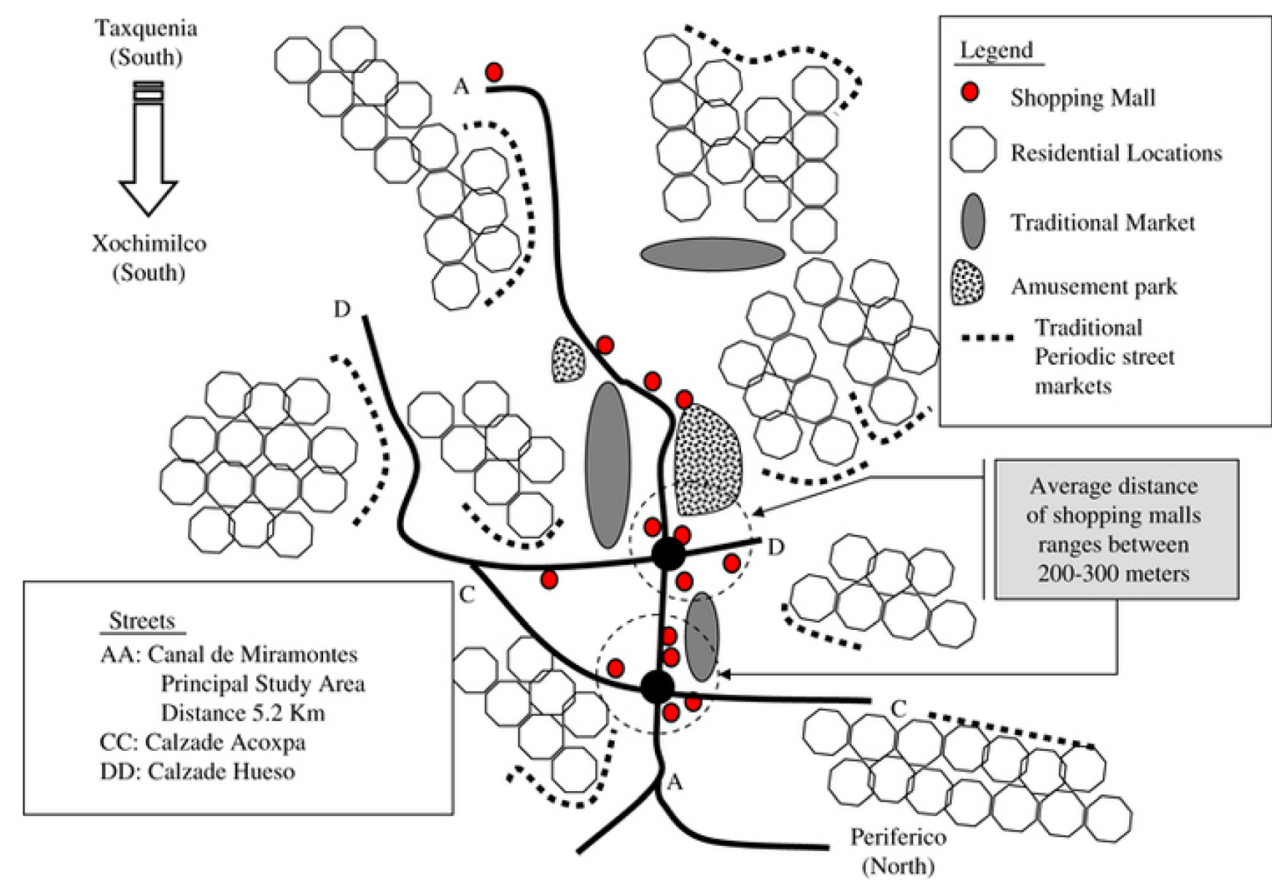

proposes a conceptual framework for the attractiveness of rail TOSMDs based on a thematic analysis. Section 4 presents a discussion on the application of the framework of rail TOSMDs' attractiveness. Finally, the paper concludes by summarising the major findings from the review, the conceptual framework for the attractiveness of rail TOSMDs, and the implications and limitations of its use.

\section{Methods and Literature Review}

We took the literature elements of the extended service marketing mix and the TOD concept in order to understand the varying range of attractiveness factors related to shopping malls and the design of TODs, as shown in Fig. 3 to establish a conceptual framework for the attractiveness of rail TOSMDs.

The authors systematically performed an online review of the attractiveness factors of shopping malls and design factors of TODs under the retail and urban land use planning literature. We identified the studies through the search procedure adopted by Busse and Siebert [20]. Using a deductive approach in our search, we limited the literature search to English empirical journals and conference proceedings after 2007. The search summary results are shown in Table 1.

Next, an iterative search of the identified articles resulted in reviewing 208 related articles to identify rail TOSMDs' attractiveness factors. The identified factors were analysed and thematically reclassified using the generic extended service marketing mix (product, price,

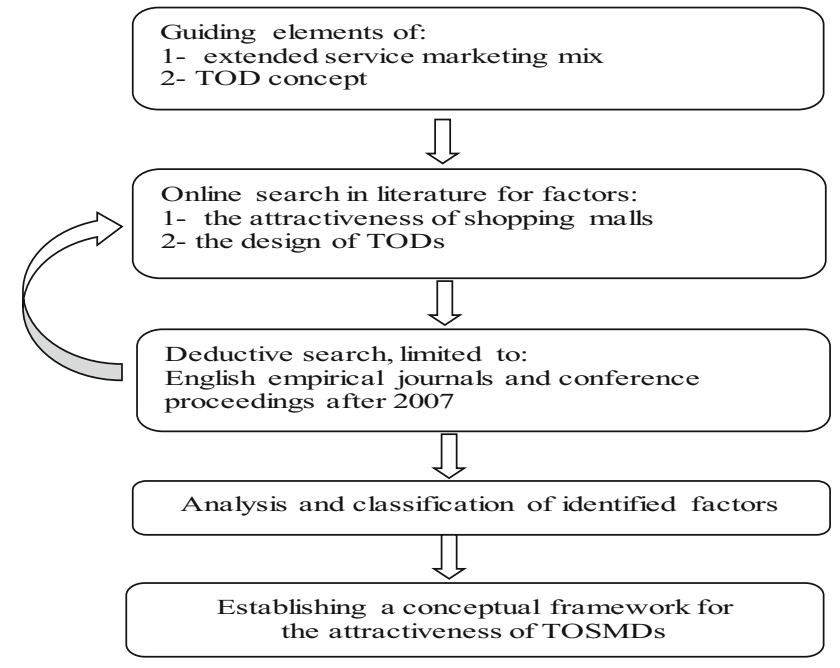

Fig. 3 Research method

place, promotion, people, physical evidence, and process) and the 5 Ds (density, diversity, urban design, destination accessibility, and distance) of TOD [21] to establish a conceptual framework for the attractiveness of rail TOSMDs.

\subsection{Attractiveness Factors of Shopping Malls}

According to Feinberg and Meoli [22], shopping malls emerged in 1907 in Baltimore, Maryland, USA, where a group of stores established off-street parking. In 1922, a group of stores only accessible by car was built in suburban Kansas City. The first enclosed shopping mall was 
Table 1 Statistics of journals and conference proceedings

\begin{tabular}{|c|c|c|c|}
\hline $\begin{array}{l}\text { Search dimensions } \\
\text { of TOSMDs }\end{array}$ & Search identifier & $\begin{array}{l}\text { Number of journals and } \\
\text { conference proceedings }\end{array}$ & Limiters \\
\hline $\begin{array}{l}\text { Shopping mall } \\
\text { attractiveness } \\
\text { factors }\end{array}$ & $\begin{array}{l}\text { (("shopping mall”) OR ("shopping centre") OR ("shopping center")) } \\
\text { AND ("attractiveness factors") }\end{array}$ & 127 & $\begin{array}{l}\text { English and } \\
\text { after } 2007\end{array}$ \\
\hline $\begin{array}{l}\text { Transit-oriented } \\
\text { development } \\
\text { factors }\end{array}$ & $\begin{array}{l}\text { ("Transit Oriented Development") AND ("factors") AND ((“shopping } \\
\text { centre") OR (("shopping center") OR ("shopping mall”)) }\end{array}$ & 81 & $\begin{array}{l}\text { English and } \\
\text { after } 2007\end{array}$ \\
\hline
\end{tabular}

developed in a suburb of Minneapolis in 1956. A shopping mall can be a separate complex of shops, department stores, services, and entertainment which simultaneously meet different needs [14]. Shopping malls are now the retail, social, and community centres of their communities. Attractiveness factors of shopping malls have been studied for different reasons, such as predicting and optimising mall patronage [23, 24], identifying the optimal mix of

Table 2 Studies in different cities on attractiveness factors of shopping malls

\begin{tabular}{|c|c|c|}
\hline Author (Ref.), location & Sample & Identified attractiveness factors of shopping malls \\
\hline $\begin{array}{l}\text { González-Hernández and Orozco-Gómez } \\
\text { [31]; Guadalajara, Mexico }\end{array}$ & 1500 consumers & $\begin{array}{l}\text { Mall essence; popularity and promotional programs; personal service; } \\
\text { recreational options; internal atmosphere; external atmosphere }\end{array}$ \\
\hline El-Adly [26]; UAE & $\begin{array}{l}404 \text { university } \\
\text { members }\end{array}$ & Comfort; entertainment; diversity; mall essence; convenience; luxury \\
\hline Farrag et al. [14]; Alexandria, Egypt & $\begin{array}{l}502 \text { mall } \\
\text { visitors }\end{array}$ & $\begin{array}{l}\text { Safety; bargain hunting; convenience; entertainment; freedom; appreciation of } \\
\text { modernity; self-identity }\end{array}$ \\
\hline Larsen et al. [32]; USA & $\begin{array}{l}515 \text { college } \\
\text { students }\end{array}$ & $\begin{array}{l}\text { Product and stores assortment; perceived management efficiency; centre } \\
\text { maintenance; cleanliness; attitudes and behaviour of the staff }\end{array}$ \\
\hline Ke and Wang [30]; Wuhan, China & $\begin{array}{l}68 \text { shopping } \\
\text { centres' data }\end{array}$ & Closeness to metro line station; being in the central commercial area \\
\hline Prashar et al. [33]; Raipur, India & 263 shoppers & Mall distance; attractive façade; climatic control; cleanliness; rest benches \\
\hline Bilková et al. [34]; Bratislava, Slovakia & $\begin{array}{l}11,389 \\
\text { shopping } \\
\text { customers }\end{array}$ & $\begin{array}{l}\text { A larger selection of the offered goods; higher quality; leisure activities; opening } \\
\text { hours; parking possibilities }\end{array}$ \\
\hline $\begin{array}{l}\text { Singh and Sahay [35]; Delhi national } \\
\text { capital region, India }\end{array}$ & 200 shoppers & $\begin{array}{l}\text { Ambience; physical infrastructure; marketing focus; convenience; safety and } \\
\text { security }\end{array}$ \\
\hline $\begin{array}{l}\text { Tandon et al. [28]; New Delhi; Kolkata; } \\
\text { Chennai; and Mumbai, India }\end{array}$ & 400 shoppers & Tenant management; facilities management; atmosphere; entertainment \\
\hline Arslan et al. [24]; Bursa, Turkey & $\begin{array}{l}621 \text { young } \\
\text { consumers }\end{array}$ & Retail environment; comfort; secure environment; accessibility; leisure \\
\hline Anselmsson [36]; Lund, Sweden & 770 persons & $\begin{array}{l}\text { Atmosphere; merchandise selection; refreshments; promotional activities; } \\
\text { convenience; salespeople; merchandising policy; location }\end{array}$ \\
\hline Ahmad [37]; Jeddah, S.A. & 600 shoppers & $\begin{array}{l}\text { Product variety; aesthetic; convenience; accessibility; entertainment; service } \\
\text { quality }\end{array}$ \\
\hline Teller and Reutterer [38]; Vienna, Austria & $\begin{array}{l}1073 \text { shopping } \\
\text { mall users }\end{array}$ & Tenant mix; atmosphere \\
\hline Singh, Prashar and [39]; Dubai, UAE & 200 shoppers & Ambience; physical infrastructure; marketing focus; convenience; safety \\
\hline Gilboa and Vilnai-Yavetz [40]; Israel & $\begin{array}{l}725 \text { mall } \\
\text { visitors }\end{array}$ & Convenience; accessibility; parking; security; tenant mix \\
\hline Tsai [41]; Tokyo, Japan & $\begin{array}{l}298 \text { mall } \\
\text { shoppers }\end{array}$ & $\begin{array}{l}\text { Entertainment; atmosphere; product arrangement; service; mall image; special } \\
\text { events; refreshment }\end{array}$ \\
\hline Tsai [41]; Sydney, Australia & $\begin{array}{l}216 \text { mall } \\
\text { shoppers }\end{array}$ & \\
\hline Tsai [41]; London, UK & $\begin{array}{l}324 \text { mall } \\
\text { shoppers }\end{array}$ & \\
\hline Tsai [41]; New York, USA & $\begin{array}{l}392 \text { mall } \\
\text { shoppers }\end{array}$ & \\
\hline
\end{tabular}




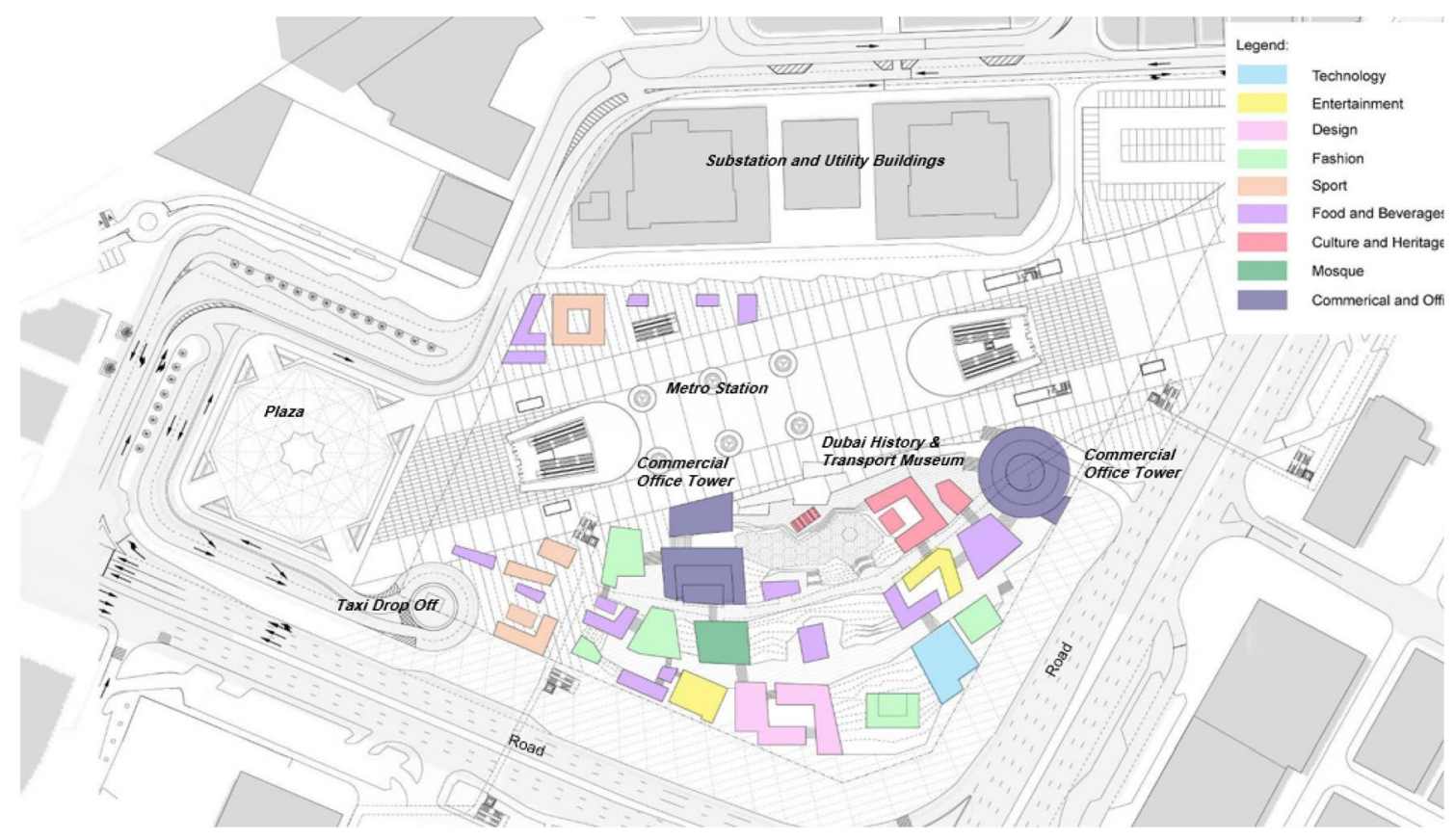

Fig. 4 Universal mixed land use TOD project design drawing and its proposed pedestrian walkways

activities in shopping malls, developing retailing strategies [25-28], understanding socio-spatial dynamics [29], and determining the malls' rent [30]. Attractiveness factors of malls can change from one context to another. The case studies in Table 2 highlight a range of attractiveness factors of shopping malls in several places.

The majority of studies on attractiveness factors of shopping malls focused solely on internal mall characteristics and their impact on mall patronage. Other studies such as Golias et al. [42] and Rajagopal [3] referred to the interrelationship between shopping malls and external context, i.e. habitation pattern, and transit system. For example, the place of a shopping mall is affected by the proximity to areas with increased population. As a result, the commercial growth in some areas led to a reduction of housing and industrial areas as land was converted to shopping malls [43]. However, the current literature does not specifically integrate internal shopping mall characteristics and its external TOD context to adequately explain factors of attractiveness of a shopping mall (pull factors) in a TOD context. We see the general characteristics of products, facilities, and the physical evidence of shopping malls were commonly identified as attractiveness factors. Table 2 shows the diversity of mall attractiveness factors in different places. Although it outlines these factors in different locations, these factors cannot solely explain the attractiveness of shopping malls. Therefore, we argue that other factors relating to the external surrounding context also need to be considered in understanding the attractiveness of a shopping mall (shopping malls pull factors), particularly in a TOD context. Therefore, the external design factors of TODs are considered in the following section to characterise this contextual surrounding environment impacting the attractiveness of shopping malls.

\subsection{Design Factors of TODs}

The term TOD became a common modern planning term when Calthorpe published The Next American Metropolis in 1993 [44]. A TOD is widely defined as a compact, mixed-use community, centred around a rail transit station that, by design, invites residents, workers, and shoppers to drive their cars less and ride mass transit more [16, 45]. It includes dense and pedestrian-friendly elements [6] and emphasises the creation of residential density and the mix of land use to attract trips, with rail transit station access mainly by foot rather than a car [17]. Figure 4 depicts a universal mixed land use TOD project and its proposed pedestrian walkways for illustration, as shown in Fig. 5.

A mixed-use shopping mall can be developed as a TOD, where shoppers drive their cars less and ride nearby mass transit [16]. TOD is an innovative sustainable solution for high-density urban planning and development [17]. By creating "activity nodes" linked by rail transit, as outlined in Fig. 6, TOD can provide mobility choices in congested areas.

TOD can increase public safety for pedestrians and rail transit users [46], increase transit ridership, reduce rates of vehicle kilometres travelled, and increase households' disposable income. This income increase is a result of the freed-up cash from reducing the need for a car and the travelling cost. It can also reduce air pollution and energy consumption rates, conserve valuable land and open space, 


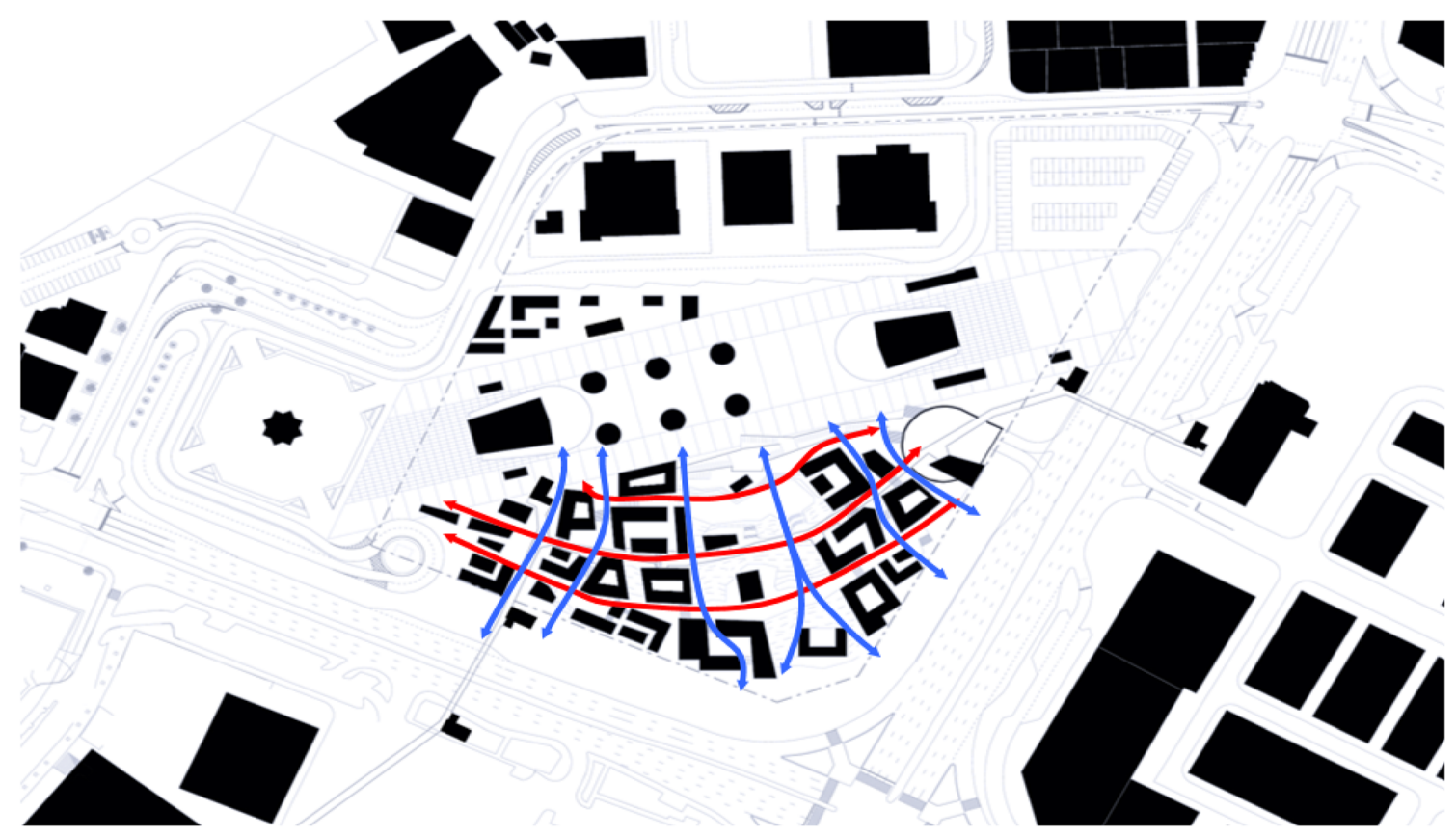

Fig. 5 Universal mixed land use TOD project proposed pedestrian walkways

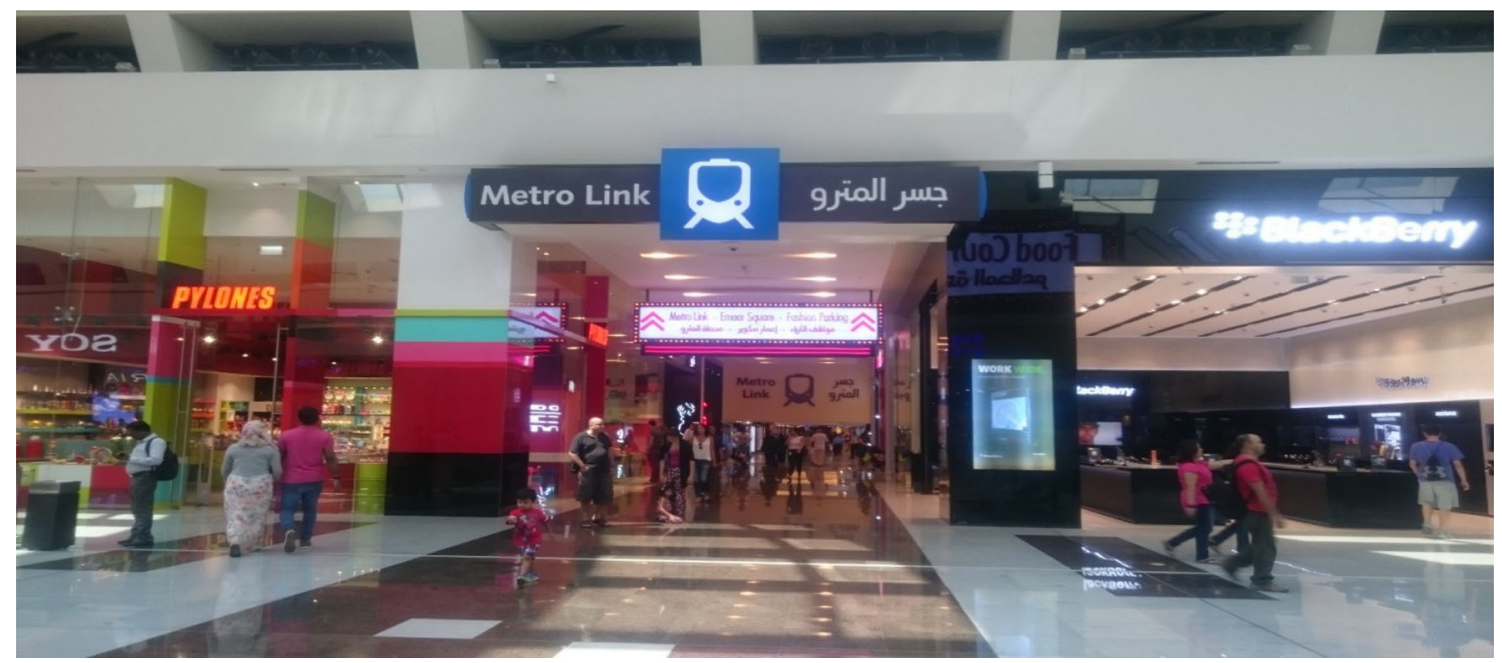

Fig. 6 Mall of the Emirates' inside link to Dubai Metro

resulting in less land used for urban developments. Consequently, it can improve economic development through transit network sustainability and neighbourhood revitalisation, and contribute to affordable housing with the compact growth pattern and the decrease in infrastructure cost [47].

Design factors of TOD have been studied for different reasons, such as assisting rail transport planners to improve transport sustainability [48], leveraging benefits and quality of urban design [17, 49], urban city policymaking and encouraging the use of public transport $[6,50,51]$, optimising investments schemes around transit stations [52], and rail transit ridership forecasting [53]. The effective design factors of a TOD can change from one context to another, e.g. zones [54]. There are case studies in different cities showing a range of effective TOD design factors, as can be seen in Table 3 .

The review of the literature identified that urban design of the area, transport characteristics, and the distance between a development and rail transit services were commonly identified TOD factors. Table 3 shows a range of effective TOD design factors in different geographic locations. Therefore, TOD factors reflecting the surrounding context of a particular shopping mall can impact its attractiveness and the number of shopper passengers using a nearby rail transit station. 
Table 3 Studies in different countries on effective design factors of TODs

\begin{tabular}{|c|c|c|}
\hline Author (Ref.), location & Sample & Identified effective design factors of TODs \\
\hline $\begin{array}{l}\text { Searle et al. [49]; } \\
\text { Melbourne, Sydney, } \\
\text { Brisbane-Australia }\end{array}$ & 8 interviewees and an online survey & $\begin{array}{l}\text { Location within larger activity centres, for commercial } \\
\text { development at smaller-scale TODs }\end{array}$ \\
\hline $\begin{array}{l}\text { Yap and Goh [6]; } \\
\text { Malaysia }\end{array}$ & 103 respondents & $\begin{array}{l}\text { Location; future value of the property; traffic congestion in } \\
\text { peak hours; safety; cost of living; accessibility; } \\
\text { available alternative travel modes; affordability of } \\
\text { properties; amenities; availability of private } \\
\text { transportation; convenience of public transportation; } \\
\text { time-saving }\end{array}$ \\
\hline Zeng [55]; China & 478 surveys & $\begin{array}{l}\text { Location close to workplace; public transport; shopping } \\
\text { centre }\end{array}$ \\
\hline $\begin{array}{l}\text { Loo et al. [53]; Hong } \\
\text { Kong, China }\end{array}$ & 79 stations in Hong Kong & $\begin{array}{l}\text { Land use; station characteristics; socioeconomic and } \\
\text { demographic characteristics; inter-modal competition }\end{array}$ \\
\hline $\begin{array}{l}\text { Loo et al. [53]; New } \\
\quad \text { York, USA }\end{array}$ & 406 stations in New York & \\
\hline $\begin{array}{l}\text { Olaru et al. [17]; Perth, } \\
\text { Australia }\end{array}$ & 509 respondents & $\begin{array}{l}\text { Physical features; social dimension; proximity to transport } \\
\text { facilities; facilities in 5-min driving distance; facilities } \\
\text { in 5-min cycling and walking distance }\end{array}$ \\
\hline $\begin{array}{l}\text { Taehyun et al. [56]; } \\
\text { Seoul, South Korea }\end{array}$ & $\begin{array}{l}\text { The Seoul field survey data on pedestrian traffic volume } \\
\text { and metro ridership in } 2009\end{array}$ & $\begin{array}{l}\text { Walking on wider streets, whereas narrower streets were } \\
\text { preferred in areas further from the metro station; street } \\
\text { connectivity; mixed land use }\end{array}$ \\
\hline $\begin{array}{l}\text { Sun et al. [57]; Beijing, } \\
\text { China }\end{array}$ & 495 surveys & $\begin{array}{l}\text { Connectivity; pedestrian-friendly designs; higher building } \\
\text { coverage ratio around the metro station }\end{array}$ \\
\hline $\begin{array}{l}\text { Kamruzzaman et al. } \\
\text { [58]; Brisbane, } \\
\text { Australia }\end{array}$ & 1734 census collection districts (CCDs) data & $\begin{array}{l}\text { Node connectivity; frequency and diversity of transport } \\
\text { services; walkable distance; number of residents in the } \\
\text { areas; workers degree of land-use diversity }\end{array}$ \\
\hline $\begin{array}{l}\text { Zemp et al. [59]; } \\
\text { Switzerland }\end{array}$ & $\begin{array}{l}\text { Swiss Federal Railway's (SBB) railway station database } \\
\text { and an earlier study by Reusser et al. [60], } 1700 \\
\text { passenger train stations density }\end{array}$ & $\begin{array}{l}\text { Location of railway tracks; centrality of the station; size of } \\
\text { catchment area; concentration; access to railway station; } \\
\text { customer types distribution; proximate urban density; } \\
\text { reputation of vicinity; cultural heritage and historical } \\
\text { reference management; connection frequencies; } \\
\text { network density; interconnection quality; reputation of } \\
\text { public transport; relative attractiveness of private } \\
\text { transport }\end{array}$ \\
\hline $\begin{array}{l}\text { van Lierop et al. [61]; } \\
\text { USA }\end{array}$ & 5 interviews with professionals & $\begin{array}{l}\text { Physical design; transportation; environment; economy; } \\
\text { collaborations; accessibility }\end{array}$ \\
\hline $\begin{array}{l}\text { van Lierop et al. [61]; } \\
\text { Canada }\end{array}$ & 2 interviews with professionals & \\
\hline $\begin{array}{l}\text { van Lierop et al. [61]; } \\
\text { Netherlands }\end{array}$ & 6 interviews with professionals & \\
\hline
\end{tabular}

Therefore, we argue that, in identifying the attractiveness factors of rail TOSMDs, there is a need to consider both the shopping mall attractiveness factors and the TOD design factors jointly. There is also the potential to thematically outline these factors, which have been partly identified in this section and will be discussed in Sect. 3 to establish a conceptual framework for rail TOSMD attractiveness. The conceptual framework will lay the foundation to support the forecast of the number of shopper passengers using a rail transit station near to a TOSMD and potentially enhance existing mobility forecasting models of the number of passengers using the rail transit station near the shopping malls.

\section{The Conceptual Framework for TOSMD Attractiveness}

The objective of this study is to clarify the attractiveness factors of rail TOSMDs and establish a conceptual framework explaining the attractiveness of TOSMDs. Existing literature does not comprehensively integrate attractiveness factors of shopping malls and design factors of TOD into a single framework that could help to explain rail TOSMD attractiveness, although both shopping mall attractiveness factors and TOD design factors jointly impact the number of shopper passengers using a nearby rail transit station in a TOD context. Section 2 identified 


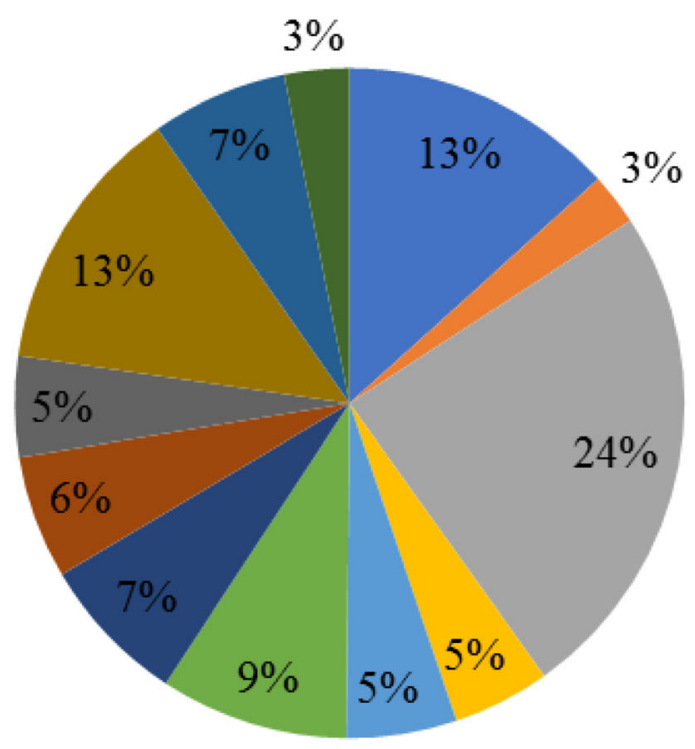

$\begin{array}{llll}\square \text { Product } & \square \text { Price } & \square \text { Place } & \square \text { Promotion } \\ \square \text { People } & \square \text { Physical Evidence } & \square \text { Process } & \square \text { Density } \\ \square \text { diversity } & \square \text { Urban design } & \square \text { Destination accessibility } & \square \text { Distance }\end{array}$

Fig. 7 Indicative weight percentages of the above themes from the study-reviewed cases

the diverse factors underpinning and resulting in shopping mall attractiveness and TOD effective design. Therefore, a generic theoretical framework was used to combine all the literature-identified factors of shopping mall attractiveness and TOD design using the generic extended service marketing mix [62] and the five dimensions (5 Ds, density, diversity, urban design, destination accessibility, and distance) of TOD [21] to establish the framework for rail TOSMD attractiveness. Both types of factors identified in Sect. 2 are thematically presented.

Firstly, the attractiveness factors of shopping malls can be viewed across the following seven dimensions:

\begin{tabular}{ll}
\hline Product & $\begin{array}{l}\text { It relates to the shopping mall product attributes, in } \\
\text { the form of shop types [26, 63], quality [37], } \\
\text { variability, and availability [31, 37], the provision } \\
\text { and characteristics of mall products [3, 31, 64, 65], } \\
\text { and activities [26, 41, 63]. Activities could be } \\
\text { leisure and entertainment, cultural activities, } \\
\text { cinemas, or game parlours } \\
\text { It relates to the shopping mall pricing attributes, in } \\
\text { the form of competitive prices and discounts given } \\
\text { at groups of shops in a particular mall. Examples } \\
\text { are factory outlet malls [66], bargains [14, 28, 38], } \\
\text { price payment options [27], and pricing strategies. } \\
\text { Pricing strategies vary from everyday low pricing } \\
\text { (EDLP) and promotional pricing (hi-lo pricing) } \\
\text { [67] } \\
\text { It relates to the shopping mall place attributes, in the } \\
\text { form of mall space [35, 68] mall stores and }\end{array}$ \\
Place &
\end{tabular}

facilities [41, 63, 64], and mall location $[30,31,36,37,40]$

Promotion It relates to the shopping mall promotional activities, in the form of the mall's promotional campaigns and events [26, 35, 39], incentives and loyalty programs $[31,64]$, and the mall's advertising $[26,36,41]$

People It relates to the shopping mall personnel interaction attributes, in the form of the mall's staff helpfulness and friendliness [36, 41, 69], their extended working hours $[3,27,36]$, their services offered [14], and the mall's crowdedness $[14,28,63]$

Physical It relates to the shopping mall exterior and interior evidence environment, in the form of the tangible mall's servicescape $[14,28]$, internal facilities, and service facilities [14, 26, 28, 35]

Process It relates to the elements and issues associated with the shopping experience in the shopping mall. It could be in the form of ease of the mall's search process for products and stores [14, 27, 70]. Another form could be in the mall's service offering process, such as home delivery $[27,37,64,70]$. Also, an additional form could be in the mall's management process, such as crowd management, space management, and freedom $[28,63]$ 


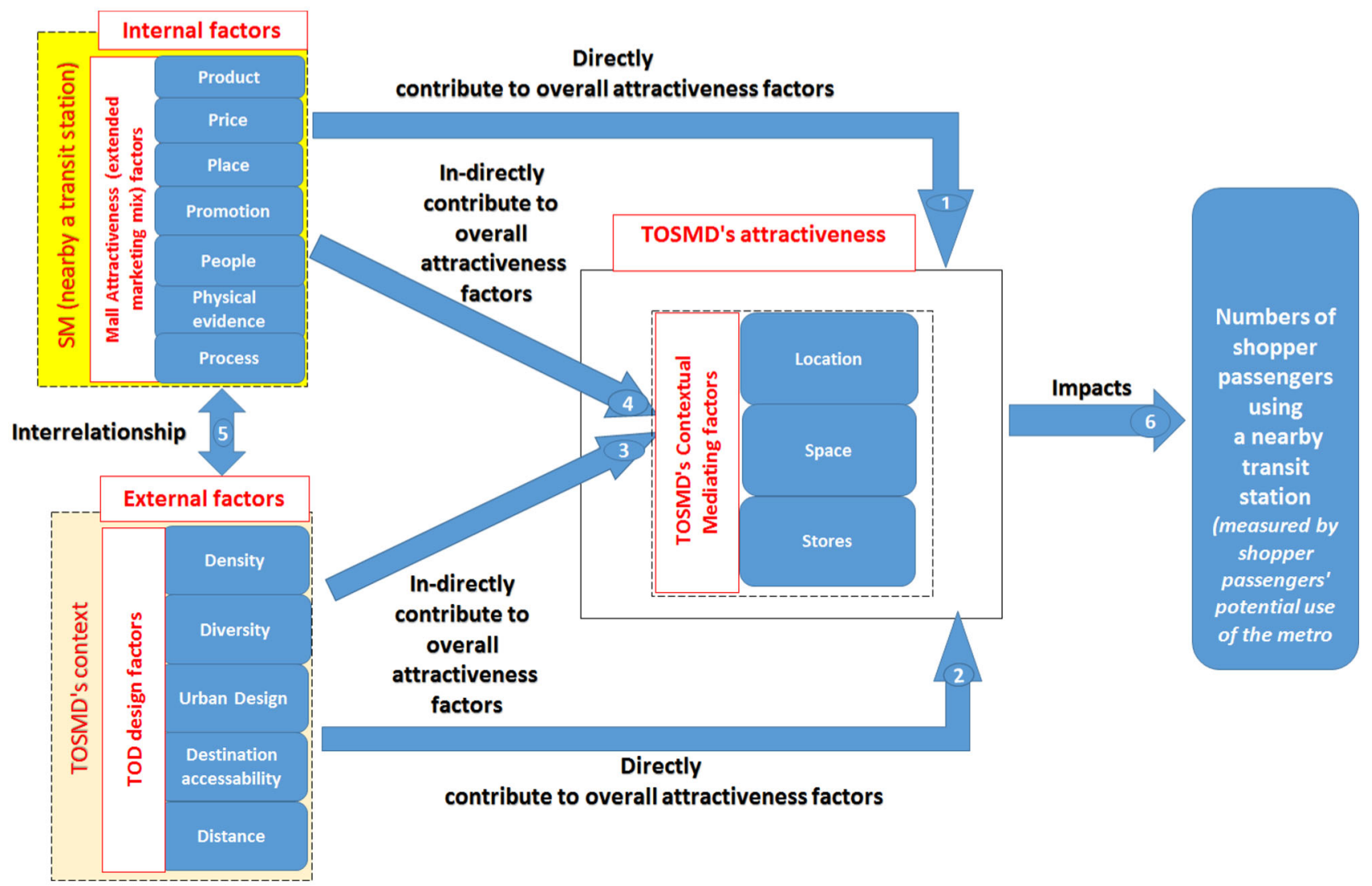

Fig. 8 The proposed conceptual framework for TOSMD attractiveness

Secondly, the design factors of TOD can be considered across the following five dimensions:

\begin{tabular}{|c|c|}
\hline Density & $\begin{array}{l}\text { It relates to agglomeration and the number of } \\
\text { business establishments in a given area [71], } \\
\text { built-up area and floor area ratios }[57,72,73] \text {, } \\
\text { and population [60,61, 73]. Hence, it was } \\
\text { divisible into a node (e.g. rail transit station) } \\
\text { and place (e.g. neighbourhood) components } \\
\text { [59]. The idea is that a development with high } \\
\text { population density is an indication of high } \\
\text { travel demand, possibly high transit ridership, } \\
\text { and hence high TOD levels in the area of the } \\
\text { development [74] }\end{array}$ \\
\hline Diversity & $\begin{array}{l}\text { It relates to mixed-use developments' attributes; } \\
\text { such as the presence of shops, services, and } \\
\text { facilities }[17,57,75] \text {. It also relates to diverse } \\
\text { environment measures, such as the presence of } \\
\text { scenic and recreational areas }[17,61,75] \text {, } \\
\text { socioeconomically diverse neighbourhoods } \\
\text { [72], and land-use homogeneity and } \\
\text { dissimilarity [76, 77] }\end{array}$ \\
\hline Urban-design & $\begin{array}{l}\text { It relates to walkability, such as increasing } \\
\text { alternative walkways }[6,57,58,78] \text {, and walk- } \\
\text { encouraging design such as reduced parking } \\
\text { areas }[61,75] \text {. Walk-encouraging design could } \\
\text { also be applied to environment and landscaping } \\
{[61,75] \text {, buildings }[43,61,75] \text {, business places }} \\
{[61,75] \text {, and connections }[57,72,75] \text {. It also }}\end{array}$ \\
\hline
\end{tabular}

relates to cycling-encouraging design, such as cycling ways and cycling areas $[6,17,60]$

Destination- It relates to the destination's availability of accessibility parking supply and proximity to transit. Destination accessibility could be in the form of walking access $[43,56,75]$, facilities access $[43,57,58,79]$, and transport access $[17,60,61,75]$

Distance It relates to proximity to transport, the location of rail and bus stations, transport-related service facilities, travel time, and mass rapid transit $[17,61,73]$. TOD, by definition, invites walking for 5-10 min, which is approximately 400-800 m [6]. Studies show that beyond this walking distance, access trips increasingly use cars. Car usage increases as distance increases from the transit station [47]. This increased car usage results in deteriorating traffic conditions and creates the need for parking spaces.

Using the elements of the extended service marketing mix and the 5 Ds of TOD, the study developed a conceptual framework for rail TOSMD attractiveness. The above themes can attract different weights in different contexts. Although a large number of studies related property value and rent. i.e. in a shopping mall to the distance from a 
Table 4 Pros and cons of association between TOD factors and attractiveness of a TOSMD

\begin{tabular}{|c|c|c|}
\hline TOD factors & $\begin{array}{l}\text { Pros of association between TOD factors and attractiveness of } \\
\text { a TOSMD }\end{array}$ & $\begin{array}{l}\text { Cons of association between TOD factors and attractiveness of } \\
\text { a TOSMD }\end{array}$ \\
\hline Density & $\begin{array}{l}\text { It could optimise the prospective number of shoppers, as high } \\
\text { population density is an indication of high travel demand } \\
\text { and also possibly high patronage [74] }\end{array}$ & $\begin{array}{l}\text { It could increase congestion [18] and eventually make the mall } \\
\text { and the area less attractive to some shoppers }\end{array}$ \\
\hline Diversity & $\begin{array}{l}\text { Commercial growth in some areas led to a reduction in } \\
\text { housing and industrial areas as land was converted to } \\
\text { shopping malls [43] }\end{array}$ & $\begin{array}{l}\text { The question is what mixtures will optimise effective mixed- } \\
\text { use TOSMD [72] }\end{array}$ \\
\hline Urban design & $\begin{array}{l}\text { It could potentially optimise the attractiveness of a TOSMD. It } \\
\text { is common to see metro stations connected with a nearby } \\
\text { TOSMD via a walking bridge to encourage and facilitate } \\
\text { coming to the mall via public transport and walking from } \\
\text { the station to the mall }\end{array}$ & $\begin{array}{l}\text { We showed earlier that some studies showed a negative } \\
\text { impact of increased crime, noise, and vibration (as a result } \\
\text { of train movement), which in turn could cause shopping } \\
\text { malls near a transit station to be less preferred }[47,83]\end{array}$ \\
\hline $\begin{array}{l}\text { Destination } \\
\text { accessibility }\end{array}$ & $\begin{array}{l}\text { Mall developments could benefit from accessibility by a } \\
\text { transit system. In addition to a higher number of prospective } \\
\text { shoppers, it could lead to greater tenant occupancy and rent } \\
{[30]}\end{array}$ & $\begin{array}{l}\text { Attractiveness is not always the case for TOSMDs with } \\
\text { accessibility by a transit station. We showed earlier that this } \\
\text { could negatively bring crime and noise pollution to the mall }\end{array}$ \\
\hline Distance & $\begin{array}{l}\text { It was explained earlier that the short walking distance } \\
\text { encourages prospective shoppers. Therefore, it optimises } \\
\text { attractiveness of a TOSMD [58] }\end{array}$ & $\begin{array}{l}\text { Attractiveness is not always the case for TOSMDs with a near } \\
\text { transit station. Similarly, it could negatively bring crimes } \\
\text { and noise pollution to the mall }\end{array}$ \\
\hline
\end{tabular}

transit station [80-82], other studies showed the negative impact of crime, noise, and vibration (as a result of train movement) increase, which in turn caused properties near a transit station to be less preferred and cheaper [47, 83]. However, this is not the case in all TODs. Mu and Jong [7] argued that density is considered important for TOD, but it is not critical, as it is well known that there are many American and European cities that do not possess density levels as high as those of Asian cities, and they have successfully become transit-oriented metropolises, but it is not the case in all TODS. Figure 7, however, shows indicative weight percentages of the above themes from the studyreviewed cases. It shows place and urban design as being highly identified factors impacting the attractiveness of TOSMDs.

The conceptual framework for the attractiveness factors of TOSMDs is depicted in Fig. 8. It is based on two concepts. Firstly, the context-based station classification of Zemp et al. [59], where differing surrounding contexts impact the attractiveness of TOSMDs. Secondly, the nodeplace concept [84, 85], where a TOSMD impacts the number of shopper passengers using its nearby rail transit station (the node). The conceptual framework combines the elements of the extended service marketing mix and the 5 Ds of TOD. The framework-independent variables of a shopping mall's attractiveness factors (internal factors) and TOD design factors (external factors), and the mediating variables of location, space, and stores (TOSMD's mediating factors) are used in determining TOSMD attractiveness without any particular weight as it varies in different contexts according to the study review. As it can be seen in
Fig. 8, there is an interrelationship between the internal shopping mall attractiveness and the external TOD. Furthermore, TOSMD attractiveness is closely linked to the number of shopper passengers using a nearby rail transit station. This number is measured by shopper passengers' potential use of the rail transit station near the shopping mall. The arrows indicate the causal links among the elements of the framework in Fig. 8.

The basic elements of the framework are as follows. Firstly, the attractiveness factors (product, price, place, and promotion) of a particular shopping mall (internal factors) impact and determine the attractiveness of a rail TOSMD. However, the extended service marketing mix factors (people, physical evidence, and process) of a particular shopping mall near a transit station also have a direct impact on the rail TOSMD's attractiveness, as shoppers tend to use tangible TOSMDs' servicescape cues to assess the intangible quality of the received services of the TOSMD. This relationship is depicted by arrow 1 .

Secondly, TOD design factors (external factors), reflecting the surrounding context of a particular TOSMD, have a direct impact on TOSMD attractiveness. For example, a high-density TOD could make a TOSMD less attractive due to human congestion in the vicinity of the TOD context. This relationship is depicted by arrow 2 . The study's conceptual framework addresses the one-way impact of TOD measures on TOSMD attractiveness, the "pull effect" (refer to Sect. 1).

Thirdly, TOD design factors also have an indirect impact on TOSMD attractiveness. They determine the mediating contextual factors of location, space, and stores 


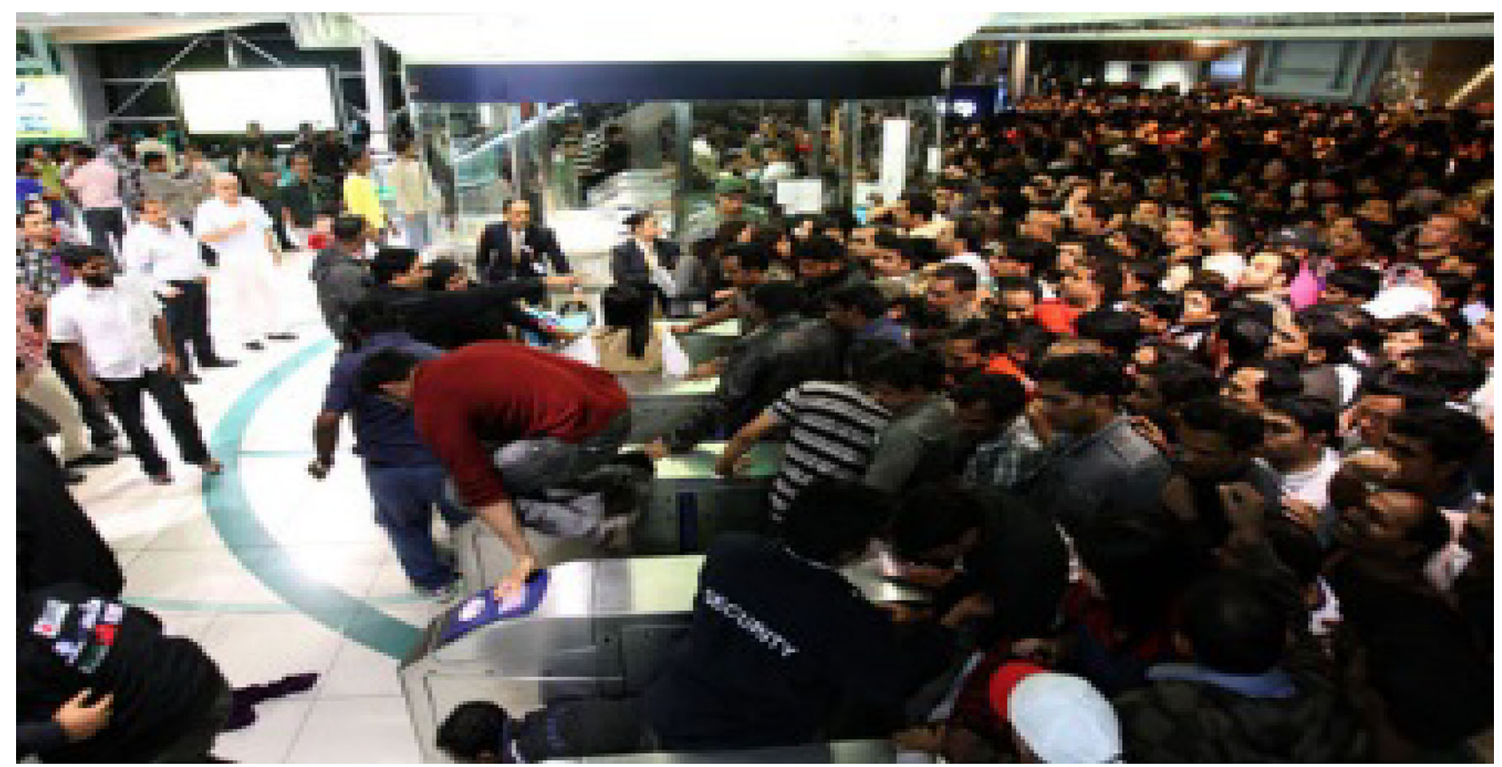

Fig. 9 Illustrative example of service disruption. Adapted from Kasmi [87]

(internal and external environment distinguishing mediating factors), such as the location of the TOSMD's outdoor dining and events areas, parking space available, and access to the TOSMD. Proximity to a rail station and other facilities determine the location-mediating factor attributes of a TOSMD. High population density can increase TOSMD's shopper numbers, impact the space and store attributes of a TOSMD, and make it more attractive. The stores mediating factor attributes of a TOSMD are impacted by the mixed use of the TOSMD's context (diversity) and the agglomeration of other businesses (density). The relationship between TOD design factors and the TOSMD's mediating factors of location, space, and stores is depicted by arrow 3 .

External TOD factors of density, diversity, urban design, destination accessibility, and distance could have a positive or negative impact on the attractiveness of a TOSMD, as explained in Table 4.

Fourthly, the shopping mall attractiveness factors indirectly impact TOSMD attractiveness. They determine the attributes of the TOSMD's mediating factors of location, space, and stores, and could optimise the shopper numbers and retail strategies of a particular shopping mall (that is, near a transit station). This relationship between the attractiveness factors of a shopping mall and the TOSMD's mediating factors of location, space, and stores is depicted by arrow 4 .

Fifthly, the interrelationship between the internal shopping mall attractiveness and its external TOD factors is depicted by arrow 5 . The interrelationship among the different factors varies in different contexts, as we mentioned earlier in this section.
Sixthly, the TOSMD's attractiveness factors impact the numbers of shopper passengers using a nearby rail transit station (node). This number can be measured by shopper passengers' potential use of the metro station near the shopping mall. This relationship is depicted by arrow 6 .

\section{Application of the Conceptual Framework}

The conceptual framework in Sect. 3 presented the relationships between shopping mall attractiveness factors and TOD design factors and their impacts on the attractiveness of TOSMD (refer to Fig. 8). These relationships impact the number of shopper passengers using a nearby rail transit station. Both shopping mall attractiveness (internal) factors and TOD design (external) factors directly impact the attractiveness of a TOSMD. These internal and external factors indirectly impact the attractiveness of a TOSMD via the TOSMD's contextual (internal and external environment distinguishing) mediating factors of location, space, and stores of the TOSMD. These mediating factors identify and clarify the TOSMD's context.

In order for the conceptual framework to be applied, it requires the collection of a range of data. A quantitative data collection approach is considered to be the most appropriate as it is typically used in generalisable causal relationships $[19,86]$. In the conceptual framework, the attractiveness of a TOSMD is clarified using the shopping mall attractiveness factors (internal factors) and the TOD design factors (external factors). The independent variables are considered to be these internal and external factors. The first dependent variable is the TOSMD attractiveness. The 
framework identifies that location, space, and stores are mediating variables of the external and internal factors' impact on the attractiveness of a TOSMD. The framework also identifies that the dependent variable of TOSMD attractiveness is, in turn, a mediator for the impact of the internal and external factors on the second dependent variable of the number of shopper passengers using a nearby metro station.

Critical data at various levels will be required to operationalise the framework. First, at the rail transit station level, the required data would include the station's design details and its connections with other modes of transport. At the mall level, data to support the framework would include the mall's size, daily shopper numbers, and mall design details. At the surrounding TOD area level, data would be required for the station and its immediate surrounding area design details, demographic and statistical details of the population around both the station and the TOSMD, the distance between the TOSMD and the nearby rail station, and the geographical and urban characteristics of the TOD area around the rail station. Next, at the passenger level, daily passenger numbers in the station near the shopping mall, including characteristics of shopper and non-shopper passengers, will support the framework. Finally, data regarding the shopper passengers' attitudes, including factors driving shopper passengers' views of the attractiveness of a TOSMD near a transit station, will be necessary. These levels of data might be sourced from multiple sources, including the relevant transportation authority and passengers coming from the TOSMD to the nearby transit station.

The literature review in Sect. 2 identified that the attractiveness factors of a TOSMD impacting the number of shopper passengers at a nearby rail transit station could change from one context to another. Therefore, the study's conceptual framework of TOSMD attractiveness could potentially be utilised to lay the foundation for informing and potentially enhancing a rail transit station's passenger forecasting models. It could be applied by (a) offering mall developers and managers a basis to distinguish and classify TOSMDs, and (b) clarifying the interrelation between the number of shopper passengers and the usage of the rail transit stations near TOSMDs. The enhancement of passenger forecasting models could better direct government spending to where the best effect would be achieved when building or improving metro stations and increase the economic sustainability of rail transit networks.

Hence, the study's conceptual framework is considered useful for cities with large numbers of shopping malls and cities growing their mall developments and connecting them with nearby rail transit stations. Rail transit stations near TOSMDs could reach their capacities in a shorter period than other stations further away from malls.
Reaching a transit station's capacity can result in costly upgrades and disruption to the rail transit service and passengers, as illustrated in Fig. 9.

The conceptual framework has limitations in that it is proposed to be applicable to clarify rail TOSMDs within a walkable distance of about $600-800 \mathrm{~m}$ of a rail transit station. It does not consider the reverse impact of attractiveness of TOSMDs on its surrounding TOD context as it is beyond the purpose of this study. It also does not consider the other factors of ridership impacting the rail transit station, such as level of rail transit service, intermodal connections, external connectivity, and other modal choice behaviours of shopper passengers. Furthermore, this study has a limitation that it is based on a literature analysis approach, and its sampling strategy was determined by the trade-off between breadth and depth of the analysis included in the study. Despite these limitations, the research contributions of this study remain valid in synthesising the literature on retail and transit urban planning into a conceptual framework for the newly introduced term of rail TOSMD pattern of development.

\section{Conclusion}

This study thematically analysed 208 guiding research articles to clarify the attractiveness factors of transit-oriented shopping mall developments (TOSMDs). It informed the creation of a conceptual framework to comprehensively explain the impact of rail TOSMD attractiveness on the demand of shopper passengers using a rail transit station near a TOSMD for potential optimal TOD effectiveness, patterns of mall development, transit urban planning, and transport policymaking. It laid the foundation for potentially enhancing existing rail transit station's passenger forecasting models.

In the literature reviewed, the term TOSMD did not exist. For this reason, the study clarified it as a shopping mall (SM) near a rail transit station in a TOD context, where both shopping mall attractiveness factors and TOD design factors impact the number of shopper passengers using a nearby rail transit station. The literature review on attractiveness (pull) factors of shopping malls focused solely on internal mall characteristics. The general characteristics of products, facilities, and physical evidence of shopping malls were commonly identified as attractiveness factors. It also emphasised the TOD design, transport characteristics, and distance as common TOD design factors. Although different factors attract different weights in different contexts, the study provided indicative weight percentages of the attractiveness factors of TOSMDs. However, it does not consider the reverse impact of attractiveness of TOSMDs on its surrounding TOD context 
as it is beyond the purpose of this study. The proposed conceptual framework for TOSMDs' attractiveness was outlined in Fig. 8. It was based on synthesising the attractiveness factors of shopping malls (internal factors) and TOD design factors (external factors), using the generic extended service marketing mix elements (product, price, place, promotion, people, physical evidence, and process) and the 5 Ds of TODs (density, diversity, urban design, destination accessibility, and distance) as an indicator system for the factors determining the attractiveness of TOSMD. Location, space, and store attributes were identified as contextual (internal and external environmentdistinguishing) mediating factors of TOSMD attractiveness. The conceptual framework also showed that the attractiveness of TOSMDs is, in turn, a mediator for the impact of the internal shopping mall attractiveness and external TOD design factors on the number of shopper passengers using a nearby metro station (node). Applying the conceptual framework to a case study will require data at the levels of the rail transit station, shopping mall, surrounding TOD area, station passengers, and shopper passengers' attitudes. The conceptual framework provides an opportunity to better refine existing passenger forecasting models by understanding the attractiveness or demand for rail TOSMDs. It can offer mall developers and managers, urban policymakers, and rail transit urban planners a basis to (a) distinguish and classify TOSMDs, and (b) clarify the number of shopper passengers using a transit rail station near a TOSMD. It is considered useful for cities that have an existing or growing number of shopping mall developments and would like to sustainably apply an effective TOD approach to their transit rail networks and shopping mall patterns of development.

\section{Compliance with ethical standards}

Conflict of interest The authors declare that they have no conflict of interest.

Open Access This article is distributed under the terms of the Creative Commons Attribution 4.0 International License (http://crea tivecommons.org/licenses/by/4.0/), which permits unrestricted use, distribution, and reproduction in any medium, provided you give appropriate credit to the original author(s) and the source, provide a link to the Creative Commons license, and indicate if changes were made.

\section{References}

1. Xia HS, Shen C, Zhang C, Wang XH, Zhang DZ (2017) Challenges in the integration of light rail and land use: a case study of Yizhuang line in Beijing. Urban Rail Transit 3(1):45-53. https:// doi.org/10.1007/s40864-017-0055-3

2. Calthorpe P (1993) The next American metropolis: ecology, community, and the American dream. Princeton Architectural Press, New York
3. Rajagopal R (2009) Growing shopping malls and behaviour of urban shoppers. J Retail Leis Prop 8(2):99-118. https://doi.org/ 10.1057/rlp.2009.3

4. Tian G, Ewing R, Weinberger R, Shively K, Stinger P, Hamidi S (2017) Trip and parking generation at transit-oriented developments: a case study of Redmond TOD, Seattle region. Transportation 44(5):1235-1254. https://doi.org/10.1007/s11116-0169702-x

5. Zhou MQ, Lin X, Mao C, Zhang K (2014) Review on the theory and planning principle of transit-oriented development. Paper presented at the 14th COTA international conference of transportation professionals, Changsha, China, July 4-7, 2014

6. Yap JBH, Goh SV (2017) Determining the potential and requirements of transit-oriented development (TOD): the case of Malaysia. Prop Manag 35(4):394

7. Mu R, Jong M (2012) Establishing the conditions for effective transit-oriented development in China: the case of Dalian. J Transp Geogr 24:234-249. https://doi.org/10.1016/j.jtrangeo. 2012.02.010

8. Zhao F, Chow L-F, Li M-T, Ubaka I, Gan A (2003) Forecasting transit walk accessibility: regression model alternative to buffer method. Transp Res Rec J Transp Res Board 1835:34-41

9. Kuby M, Barranda A, Upchurch C (2004) Factors influencing light-rail station boardings in the United States. Transp Res Part A Policy Pract 38(3):223-247

10. Gutiérrez J, Cardozo OD, García-Palomares JC (2011) Transit ridership forecasting at station level: an approach based on distance-decay weighted regression. J Transp Geogr 19(6):1081-1092. https://doi.org/10.1016/j.jtrangeo.2011.05.004

11. Handy S (2005) Smart growth and the transportation-land use connection: what does the research tell us? Int Reg Sci Rev 28(2):146-167

12. Sun Y-1, Tarigan A, Waygood O, Wang D-h (2017) Diversity in diversification: an analysis of shopping trips in six-week travel diary data. J Zhejiang Uni Sci A 18(3):234-244. https://doi.org/ 10.1631/jzus.A1500198

13. Pitt M, Musa ZN (2009) Towards defining shopping centres and their management systems. J Retail Leis Prop 8(1):39-55. https:// doi.org/10.1057/rlp.2008.25

14. Farrag DA, El Sayed IM, Belk RW (2010) Mall shopping motives and activities: a multimethod approach. J Int Consum Mark 22(2):95-115. https://doi.org/10.1080/08961530903476113

15. Lee C, Moudon AV (2008) Neighbourhood design and physical activity. Build Res Inf 36(5):395-411. https://doi.org/10.1080/ 09613210802045547

16. Bernick M, Cervero R (1997) Transit villages in the 21st century. McGraw-Hill, New York

17. Olaru D, Smith B, Taplin JHE (2011) Residential location and transit-oriented development in a new rail corridor. Transp Res Part A 45(3):219-237. https://doi.org/10.1016/j.tra.2010.12.007

18. Kok HJ (2007) Restructuring retail property markets in Central Europe: impacts on urban space. J Hous Built Environ 22(1):107-126. https://doi.org/10.1007/s10901-006-9068-z

19. Chorus P, Bertolini L (2016) Developing transit-oriented corridors: insights from Tokyo. Int J Sustain Transp 10(2):86-95. https://doi.org/10.1080/15568318.2013.855850

20. Busse M, Siebert R (2018) Acceptance studies in the field of land use- a critical and systematic review to advance the conceptualization of acceptance and acceptability. Land Use Policy 76:235-245. https://doi.org/10.1016/j.landusepol.2018.05.016

21. Cervero R, Murakami J (2008) Rail + property development: a model of sustainable transit finance and urbanism. In: UC Berkeley. Center for Future Urban Transport: a Volvo Center of Excellence. Available via eScholarship. https://escholarship.org/ uc/item/6jx3k35x. Accessed 08 Nov 2017 
22. Feinberg RA, Meoli J (1991) A brief history of the mall. Adv Consum Res 18:426

23. Wei Khong K, Sim Ong F (2014) Shopper perception and loyalty: a stochastic approach to modelling shopping mall behaviour. Int $\mathrm{J}$ Retail Distrib Manag 42(7):626-642. https://doi.org/10.1108/ IJRDM-11-2012-0100

24. Arslan TV, Sezer FS, Isigicok E (2010) Magnetism of shopping malls on young Turkish consumers. Young Consum 11(3):178-188. https://doi.org/10.1108/17473611011074250

25. Dahsh M, Dasa P (2014) Shopping mall preferences in eastern region: implications for retail strategy. Prestig Int J Manag Res 7/8(2/1):19

26. El-Adly M (2007) Shopping malls attractiveness: a segmentation approach. Int J Retail Distrib Manag 35(11):936-950. https://doi. org/10.1108/09590550710828245

27. Kushwaha T, Ubeja S, Chatterjee AS (2017) Factors influencing selection of shopping malls: an exploratory study of consumer perception. Vis J Bus Perspect 21(3):274-283. https://doi.org/10. 1177/0972262917716761

28. Tandon A, Gupta A, Tripathi V (2016) Managing shopping experience through mall attractiveness dimensions: an experience of Indian metro cities. Asia Pac J Mark Logist 28(4):634-649. https://doi.org/10.1108/APJML-08-2015-0127

29. Erkip F (2005) The rise of the shopping mall in Turkey: the use and appeal of a mall in Ankara. Cities 22(2):89-108. https://doi. org/10.1016/j.cities.2004.10.001

30. Ke Q, Wang W (2016) The factors that determine shopping centre rent in Wuhan, China. J Prop Invest Finance 34(2):172-185. https://doi.org/10.1108/JPIF-04-2015-0021

31. González-Hernández EM, Orozco-Gómez M (2012) A segmentation study of Mexican consumers based on shopping centre attractiveness. Int J Retail Distrib Manag 40(10):759-777

32. Larsen V, Shelton R, Wright ND (2015) Shopping center attitudes: an empirical test of predictive attributes. Acad Mark Stud J 19(2):93

33. Prashar S, Gupta S, Singh H, Vijay TS, Parsad C (2016) Clustering shoppers by mall experience for emerging Indian city. Asian Acad Manag J 21(2):53-73. https://doi.org/10.21315/ aamj2016.21.2.3

34. Bilková K, Krizan F, Barlík P (2016) Consumers preferences of shopping centers in Bratislava (Slovakia). Hum Geogr 10(1):23. https://doi.org/10.5719/hgeo.2015.101.2

35. Singh S (2012) Determinants of shopping experience. Int J Retail Distrib Manag 40(3):235-248. https://doi.org/10.1108/ 09590551211207184

36. Anselmsson J (2006) Sources of customer satisfaction with shopping malls: a comparative study of different customer segments. Int Rev Retail Distrib Consum Res 16(1):115-138. https:// doi.org/10.1080/09593960500453641

37. Ahmad AEMK (2012) Attractiveness factors influencing shoppers' satisfaction, loyalty, and word of mouth: an empirical investigation of Saudi Arabia shopping malls. Int J Bus Adm 3(6): 101

38. Teller C, Reutterer T (2008) The evolving concept of retail attractiveness: what makes retail agglomerations attractive when customers shop at them? J Retail Consum Serv 15(3):127-143

39. Singh H, Prashar S (2013) Factors defining shopping experience: an analytical study of Dubai. Asian J Bus Res 3(1):36

40. Gilboa S, Vilnai-Yavetz I (2012) Segmenting multicultural mall visitors: the Israeli case. Mark Intell Plan 30(6):608-624. https:// doi.org/10.1108/02634501211262582

41. Tsai S (2010) Shopping mall management and entertainment experience: a cross-regional investigation. Serv Ind J 30(3):321-337. https://doi.org/10.1080/02642060802123376

42. Golias M, Mishra S, Psarros I (2016) A guidebook for best practices on integrated land use and travel demand modeling.
Department of Civil Engineering, University of Memphis, Memphis

43. Pacheco-Raguz JF (2010) Assessing the impacts of light rail transit on urban land in Manila. J Trans Land Use. https://doi.org/ $10.5198 /$ jtlu.v3i1.13

44. Carlton I (2009) Histories of transit-oriented development: perspectives on the development of the TOD concept. Institute of Urban and Regional Development, Berkeley, CA

45. Cervero R (2004) Transit-oriented development in the United States: experiences, challenges, and prospects, vol 102. Transportation Research Board, Washington

46. Chikomba C (2014) Retail shopping mall security: raising awareness of crime risks against business in Zimbabwe (a case study of Joina City shopping mall, Harare-June 2011-July 2012). J Appl Secur Res 9(2):185-220. https://doi.org/10.1080/ 19361610.2013.825754

47. Cervero R, Ferrell C, Murphy S (2002) Transit-oriented development and joint development in the United States: a literature review. TCRP Res Results Dig 52:1-144

48. Shiau T, Huang M, Lin W (2015) Developing an indicator system for measuring Taiwan's transport sustainability. Int J Sustain Transp 9(2):81-92. https://doi.org/10.1080/15568318.2012. 738775

49. Searle G, Darchen S, Huston S (2014) Positive and negative factors for transit oriented development: case studies from Brisbane, Melbourne and Sydney. Urban Policy Res 32(4):437-457. https://doi.org/10.1080/08111146.2014.931280

50. Jones CE, Ley D (2016) Transit-oriented development and gentrification along Metro Vancouver's low-income SkyTrain corridor. Can Geogr 60(1):9-22. https://doi.org/10.1111/cag.12256

51. Yang J, Chen J, Le X, Zhang Q (2016) Density-oriented versus development-oriented transit investment: decoding metro station location selection in Shenzhen. Transp Policy 51:93-102. https:// doi.org/10.1016/j.tranpol.2016.04.004

52. Peng Y, Li Z, Choi K (2017) Transit-oriented development in an urban rail transportation corridor. Transp Res Part B 103:269-290. https://doi.org/10.1016/j.trb.2017.03.011

53. Loo BPY, Chen C, Chan ETH (2010) Rail-based transit-oriented development: lessons from New York City and Hong Kong. Landsc Urban Plan 97(3):202-212. https://doi.org/10.1016/j. landurbplan.2010.06.002

54. Moudon A, Sohn DW, Kavage SE, Mabry JE (2011) Transportation-efficient land use mapping index (TELUMI), a tool to assess multimodal transportation options in metropolitan regions. Int J Sustain Transp 5(2):111-133. https://doi.org/10.1080/ 15568311003624262

55. Zeng R (2013) Attributes influencing home buyers' purchase decisions: a quantitative study of the Wuhan residential housing market

56. Taehyun K, Dong-Wook S, Sangho C (2016) An analysis of the relationship between pedestrian traffic volumes and built environment around metro stations in Seoul. KSCE J Civ Eng. https:// doi.org/10.1007/s12205-016-0915-5

57. Sun G, Zacharias J, Ma B, Oreskovic NM (2016) How do metro stations integrate with walking environments? Results from walking access within three types of built environment in Beijing. Cities 56:91-98. https://doi.org/10.1016/j.cities.2016.03.001

58. Kamruzzaman M, Baker D, Washington S, Turrell G (2014) Advance transit oriented development typology: case study in Brisbane, Australia. J Transp Geogr 34:54-70. https://doi.org/10. 1016/j.jtrangeo.2013.11.002

59. Zemp S, Lang S (2011) Classifying railway stations for strategic transport and land use planning: context matters! J Transp Geogr 19(4):670-679

60. Reusser L, Stauffacher S (2008) Classifying railway stations for sustainable transitions-balancing node and place functions. 
J Transp Geogr 16(3):191-202. https://doi.org/10.1016/j.jtrangeo. 2007.05.004

61. van Lierop D, Maat K, El-Geneidy A (2017) Talking TOD: learning about transit-oriented development in the United States, Canada, and the Netherlands. J Urban Int Res Placemaking Urban Sustain 10(1):49-62. https://doi.org/10.1080/17549175.2016. 1192558

62. Rafiq M, Ahmed PK (1995) Using the 7Ps as a generic marketing mix: an exploratory survey of UK and European marketing academics. Mark Intell Plan 13(9):4-15. https://doi.org/10.1108/ 02634509510097793

63. Khare A (2011) Mall shopping behaviour of Indian small town consumers. J Retail Consum Serv 18(1):110-118. https://doi.org/ 10.1016/j.jretconser.2010.10.005

64. Rajagopal R (2011) Determinants of shopping behavior of urban consumers. J Int Consum Mark 23(2):83-104. https://doi.org/10. 1080/08961530.2011.543051

65. Rajagopal R (2010) Coexistence and conflicts between shopping malls and street markets in growing cities: analysis of shoppers' behaviour. J Retail Leis Prop 9(4):277-301. https://doi.org/10. 1057/rlp.2010.17

66. Reynolds KE, Ganesh J, Luckett M (2002) Traditional malls vs. factory outlets: comparing shopper typologies and implications for retail strategy. J Bus Res 55(9):687-696. https://doi.org/10. 1016/s0148-2963(00)00213-7

67. Leszczyc PTP, Sinha A, Sahgal A (2004) The effect of multipurpose shopping on pricing and location strategy for grocery stores. J Retail 80(2):85-99

68. Wang D, Zhou M (2016) The built environment and travel behavior in urban China: a literature review. Transp Res Part D Transp Environ. https://doi.org/10.1016/j.trd.2016.10.031

69. El-Adly MI, Eid R (2016) An empirical study of the relationship between shopping environment, customer perceived value, satisfaction, and loyalty in the UAE malls context. J Retail Consum Serv 31:217-227. https://doi.org/10.1016/j.jretconser.2016.04. 002

70. Devgan D, Kaur M (2010) Shopping malls in India: factors affecting Indian customers' perceptions. South Asian J Manag 17(2):29

71. Masoumi HE, Mirmoghtadaee M (2016) Editorial preface. Transit-oriented development in Iran: challenges and solutions. TeMA J Land Use. https://doi.org/10.6092/1970-9870/4028

72. Sung H, Lee S (2015) Residential built environment and walking activity: empirical evidence of Jane Jacobs' urban vitality. Transp Res Part D 41:318-329. https://doi.org/10.1016/j.trd.2015.09.009

73. Li C, Lin C, Hsieh T (2016) TOD district planning based on residents' perspectives. ISPRS Int J GeoInf 5(4):52. https://doi. org/10.3390/ijgi5040052

74. Singh YJ, Fard P, Zuidgeest M, Brussel M, Maarseveen M (2014) Measuring transit oriented development: a spatial multi criteria assessment approach for the city region Arnhem and Nijmegen. J Transp Geogr 35:130-143. https://doi.org/10.1016/j.jtrangeo. 2014.01.014

75. Jacobson F (2008) Seven American TODs: good practices for urban design in transit-oriented development projects. J Transp Land Use 1(2):51-88

76. Cervero R, Kockelman K (1997) Travel demand and the 3Ds: density, diversity, and design. Transp Res Part D 2(3):199-219. https://doi.org/10.1016/S1361-9209(97)00009-6

77. Sarkar PP, Chunchu M (2016) Quantification and analysis of land-use effects on travel behavior in smaller Indian cities: case study of Agartala. J Urban Plan Dev 142(4):4016009. https://doi. org/10.1061/(ASCE)UP.1943-5444.0000322

78. Kamruzzaman M, Shatu FM, Hine J, Turrell G (2015) Commuting mode choice in transit oriented development: disentangling the effects of competitive neighbourhoods, travel attitudes, and self-selection. Transp Policy 42:187-196. https://doi.org/10. 1016/j.tranpol.2015.06.003

79. Lund $\mathrm{H}$ (2006) Reasons for living in a transit-oriented development, and associated transit use. J Am Plan Assoc 72(3):357-366. https://doi.org/10.1080/01944360608976757

80. Duncan M (2008) comparing rail transit capitalization benefits for single-family and condominium units in San Diego, California. Transp Res Rec J Transp Res Board 2067:120-130. https://doi. org/10.3141/2067-14

81. Cervero R, Duncan M (2002) Transit's value-added effects: light and commuter rail services and commercial land values. Transp Res Rec J Transp Res Board 1805:8-15. https://doi.org/10.3141/ 1805-02

82. Ko K, Cao XJ (2013) The impact of Hiawatha light rail on commercial and industrial property values in Minneapolis. J Public Transp 16(1):47-66. https://doi.org/10.5038/2375-0901. 16.1.3

83. Bowes DR, Ihlanfeldt KR (2001) Identifying the impacts of rail transit stations on residential property values. J Urban Econ 50(1):1-25. https://doi.org/10.1006/juec.2001.2214

84. Bertolini L (1999) Spatial development patterns and public transport: the application of an analytical model in the Netherlands. Plan Pract Res 14(2):199-210. https://doi.org/10.1080/ 02697459915724

85. Bertolini L (1996) Nodes and places: complexities of railway station redevelopment. Eur Plan Stud 4(3):331-345. https://doi. org/10.1080/09654319608720349

86. Phillips DC, Burbules NC (2000) Postpositivism and educational research. Rowman \& Littlefield, Lanham

87. Kasmi M (2012) Cut in Dubai Metro boarding time raises train etiquette culture clash. emirates24/7. https://www.emirates247. com/news/emirates/cut-in-dubai-metro-boarding-time-raisestrain-etiquette-culture-clash-2012-08-01-1.469671. Accessed 21 Feb 2019 